\title{
STUDENT'S MATHEMATIC REPRESENTATION ABILITY IN MATHEMATICS PROBLEM SOLVING ON TRIANGLE MATERIALS
}

\section{KEMAMPUAN REPRESENTASI MATEMATIS SISWA DALAM PEMECAHAN MASALAH MATEMATIKA PADA POKOK BAHASAN SEGITIGA}

\author{
Zulfa Pratamaningtyas ${ }^{1}$, Dori Lukman Hakim ${ }^{2}$ \\ ${ }^{1,2}$ Universitas Singaperbangsa Karawang, Jl.H.S. Ronggowaluyo Telukjambe Timur - Karawang \\ 41361 Indonesia \\ Email: 1710631050011@student.unsika.ac.id, dorilukmanhakim@fkip.unsika.ac.id
}

\begin{abstract}
ABSTRAK
Penelitian ini menggambarkan secara deskriptif bagaimana kemampuan siswa SMP dalam menyelesaikan masalah berkaitan dengan kegiatan merepresentasikan gambar, simbol, dan verbal pada materi segitiga. Penelitian yang digunakan merupakan penelitian kualitatif dengan metode analisis deskriptif. Tahapan penelitian yang dilakukan yaitu 1) penentuan subjek penelitian, 2) penentuan instrumen penelitian, 3) pemberian soal kepada siswa, 3) pengumpulan data penelitian, 4) analisis data hasil penelitian. Hasil penelitian menunjukkan bahwa pada aspek representasi verbal, kemampuan representasi matematis siswa dalam menerjemahkan gambar ke dalam bentuk verbal sudah dimiliki siswa dengan semua tingkat kemampuan. Sedangkan kemampuan representasi siswa dalam mengungkapkan ekspresi verifikasi masih kurang. Pada representasi gambar, siswa dengan semua tingkat kemampuan sudah mampu mengungkapkan istilah yang berkaitan dengan gambar, sedangkan pada proses menggambarkan suatu gambar menggunakan kemampuan representasinya hanya siswa kemapuan tinggi yang mampu menyelesaikan permasalahan. Pada aspek kemampuan representasi simbolik, ketiga siswa sudah mampu mengoperasikan bentuk aljabar, meskipun pada salah satu siswa kurang teliti dalam proses penyelesaiannya yang mengakibatkan hasil yang dihitung tidak benar.
\end{abstract}

Kata Kunci: Representasi Gambar, Representasi Verbal, Representasi Simbol

\begin{abstract}
This study describes descriptively how the ability of junior high school students in solving problems is related to the activities of representing images, symbols, and verbally on triangular material. The type of research used is qualitative with descriptive analysis method. The stages of the research carried out are: 1) determining the research subject;2) determination of research instruments; 3) giving questions to students; 3) research data collection; 4) research data processing; and 5) analysis of research data. The research sample was determined purposively and three seventh grade junior high school students were taken, namely one high ability student, one medium ability student, and one low ability student. The instrument used is in the form of mathematical problems that contain mathematical representation abilities taken from the Kemendikbud package book. The analysis technique used is descriptive analysis. The results showed that in the aspect of verbal representation, students' ability to translate images into verbal form was already owned by students with all levels of ability. However, for students with moderate and low abilities, verbal expression of verification is still lacking. In image representation, students with all levels of ability can express terms related to images. However, in the process of describing
\end{abstract}


something using representational abilities, only high-ability students can solve problems. In the aspect of symbolic representation, students with all levels of ability can operate algebraic forms. However, students with low abilities are less thorough and less skilled in operating algebraic forms. Keywords: Pictorial Representation, Verbal Representation, Symbolic Representation Symbol

How to Cite: Pratamaningtyas, Z \& Hakim, D. L. (2021). Student's Mathematic Representation Ability in Mathematics Problem Solving on Triangle Materials. Mathline: Jurnal Matematika dan Pendidikan Matematika, Vol. 6 No. 2, 175-190.

DOI: https://doi.org/10.31943/mathline.v6i2.225

\section{PRELIMINARY}

The increasingly advanced development requires the Indonesian people to provide superior and quality human resources. The way that can be used to improve the quality of human resources is to improve the quality of education. This is in line with the National Education Goals described in the 2003 National Education System Law, namely "National Education functions to develop capabilities and shape the character and civilization of a dignified nation in the context of educating the nation's life, aiming at developing the potential of students to become human beings who believe and fear God Almighty, have a noble character, are healthy, knowledgeable, capable, creative, independent, and become democratic and responsible citizens. Therefore, Indonesian education should be able to make the successor of the Indonesian nation superior and quality, so that it can compete with other countries. One of them is in the field of mathematics.

Mathematics is one of the subjects that is often considered complicated to be understood by students (Nurjanah \& Hakim, 2019). Its abstract nature makes students required to be able to represent mathematical material that contains pictures, graphs, diagrams, symbols, and algebraic operations into a form that is easier to understand according to their understanding. This is in line with Soedjadi (Andriani, 2015) stated that one of the characteristics of mathematics has an abstract object of study. Hakim et al, (2020) also explained that mathematics has a lot of abstraction material. Therefore, an ability is needed that can make abstract mathematics simpler. This ability is one of the aspects contained in the ability of mathematical representation.

Mathematical representation is the ability to configure shapes or arrangements that can describe, represent, symbolize mathematical ideas or situations in a certain way (Fauzan, 2013). In addition, Novianti \& Retnawati (2019) also explained that mathematical representation ability is an ability that is related to understanding mathematical concepts. 
Mathematical representation ability is the ability to describe or represent a mathematical idea in the form of pictures, diagrams, graphs, symbols, or other forms in a clearer form so that mathematical ideas can be easily understood. Mathematical representation consists of several aspects, including pictorial representation, symbol representation, and also verbal representation (Villegas, et al., 2009). Pictorial representation is a representation related to translating images into other forms or vice versa. Verbal representation is a representation related to language both orally and in writing. Symbol representation is a representation related to symbols in the form of numbers, operations, or other symbols.

Mathematical representation ability is one of the important abilities for students to have. This was also explained by Putri \& Munandar, (2020) that representation ability is needed to be mastered in learning mathematics. Following that was determined by The National Council of Teachers of Mathematics (NCTM) year 2000, five standard processes must exist in learning mathematics, including problem-solving, reasoning, communication, and connection. connection), and representation (representation). Based on this, representation is one of the capabilities mentioned in the five process standards at NCTM.

The results of research conducted by Novianti \& Retnawati, (2019) explained that the importance of mathematical representation ability is to assist students in solving mathematical problems. This is due to the characteristics of abstract mathematics. In addition, Hakim, etc (2020) also explained that mathematical representation ability is a person's mental picture in identifying mathematical ideas. The mathematical ideas represented can be in the form of images, symbols, or verbal expressions.

Triangle is one of the geometry materials taught in mathematics learning, so to understand the geometry material, students' mathematical representation abilities are needed. This is because Geometry material needed student ability to represent mathematics (Triono, 2017). In the triangle material, students must be able to calculate the circumference or area of a triangle which is presented in the form of images or verbally which often contains the $x$ variable. To calculate the area of the triangle, students must be able to translate the presented images and also operate mathematical operations, such as substituting the value of $x$ in algebraic operations. Therefore, it takes students' ability to identify the length of each side that is already known in the triangle image which is then translated into the form of mathematical operations. Students must also complete operations contain the $x$ variable to produce the final calculation result. The problems contained in the triangle material which are usually in the form of story questions also 
require the ability to translate the questions into mathematical sentences in the form of images or symbols. So students need to have the ability to represent verbal aspects.

The results showed that there were still students who had difficulties in using their representational abilities on triangle material. Students are sometimes confused in determining how to find the area of the triangle that has been described in the problem soal (Dewi \& Sopiany, 2017). In addition, in a study conducted by Sari et al, (2021) it was stated that students still had difficulty in explaining the properties of triangles using their language. Students tend to use previously learned language. In the study, it was also explained that there were still students who had difficulty in describing triangles if only given their properties. This means that these students are less able to use image representation skills in solving mathematical problems. Therefore, with mathematical representation ability, students are expected to be able to translate and represent mathematics to solve mathematical problems that are being faced.

Based on the background that has been stated above, the discussion of this article is focused on how the students' mathematical representation ability in the subject of triangles. This article aims to describe students' mathematical representation abilities on the subject of triangles, so the author wants to discuss more deeply related to students' mathematical representation abilities entitled "Students' Mathematical Representation Abilities in Solving Mathematical Problems on Triangles".

\section{METHOD}

The research used is qualitative. According to Creswell (2009), qualitative research is used to explore the understanding that is considered a social problem as well as a human problem. The research method used is the descriptive analysis method. This study aims to see how junior high school students solve triangular material problems using representational abilities descriptively. In this study, the sample was determined purposively and three students were taken, where one student with high ability, one student with moderate ability, and one student with low ability.

According to Lincoln \& Guba (Gumilang, 2016), qualitative research is research in which the researcher acts as the main instrument. Therefore, in this study, the researcher becomes the main instrument. In this case, the researcher deals directly with research activities. As the main instrument, the researcher collects information by collecting data through literature review from trusted sources, observation, interviews, and also 
documentation. Furthermore, the research data that have been collected are then analyzed and interpreted following the theories that have been studied previously.

In addition to the main instrument, in this study, the researcher also used supporting instruments. The supporting instrument used is the student's mathematical representation ability test. The instrument is in the form of two questions taken from the Kemendikbud Text Book by As'ari et al, (2013), namely Buku Siswa SMP/MTs Kelas VII the revised 2017 edition and Buku Guru SMP/MTs Kelas VII the revised 2017 edition. According to Adilah (2015), the 2013 Curriculum textbook is prepared by the government to apply the 2013 Curriculum. The textbook is prepared by competent parties and is under the coordination of the Ministry of Education and Culture which is frequently updated. Therefore, the researcher used a question instrument sourced from the Kemendikbud textbook.

This study uses descriptive data analysis. The stages in this research are 1) determining research subjects, 2) determining research instruments, 3) giving questions to students, 3) collecting research data, 4) processing research data, and 5) analyzing research data. Of the 28 students who have worked on the mathematical representation ability test, then selected purposively and taken 3 students with one low ability student, one medium ability student, and one high ability student based on the results obtained. The following is a list of the three students whose answers will be analyzed based on three aspects of mathematical representation ability, namely the pictorial aspect, the symbol aspect, and the verbal aspect.

Table 1. Classification of Research Subjects

\begin{tabular}{cc}
\hline Ability Category & Initials of Research Subject \\
\hline High & JRF \\
Middle & BSS \\
Low & SF \\
\hline
\end{tabular}

\section{RESULT AND DISCUSSION}

The research was conducted at one of the Junior High Schools in Cikarang in December 2020 by providing two questions sourced from Kemendikbud textbooks, namely Buku Siswa SMP/MTs Kelas VII the revised 2017 edition and Buku Guru SMP/MTs Kelas VII the revised 2017 edition written by As'ari et al (2013), as follows: 
1. Diketahui keliling KLM adalah $40 \mathrm{~cm}$.

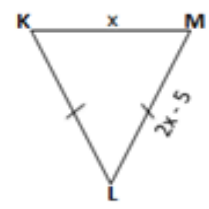

a. Berbentuk apakah segitiga KLM?

b. Tentukan panjang sisi-sisi segitiga KLM!

2. Lukislah ketiga garis bagi

a. Pada segitiga siku-siku

b. Pada segitiga tumpul

c. Kemudian apakah yang dapat kalian simpulkan tentang ketiga garis bagi pada suatu segitiga?

\section{Figure 1. Triangle Math's Test}

The results of students' answers to question number 1 are as follows:

\begin{tabular}{|c|c|}
\hline SF Students & BSS Students \\
\hline 6. Seatioa sama kak4 $40=2 x-5^{2}+x$ & $k_{\|}=40 \mathrm{~cm} \quad \mathrm{k} \quad \mathrm{x}, M$ \\
\hline b. Panonesisi $=214 t^{2}=c^{2}$ & 5 \\
\hline $5 x=30$ & $2 x-5$ \\
\hline$\overline{5}$ & L \\
\hline$x=6 \quad(1)$ & $k \|=(2 x-5)+(2 x-5)+x$ \\
\hline JRF Students & $\begin{array}{l}40=5 x-10 \\
40=5 x-10\end{array}$ \\
\hline a. Segitiga sama kaki & $\begin{aligned} 40+10 & =5 x \\
50 & =5 x\end{aligned}$ \\
\hline b. $\quad 2(2 x-5)+x=40 \mathrm{~cm}$ & $x=50: 5$ \\
\hline $4 x-10+x=40$ & $x=10$ \\
\hline D. $4 x+x=40+10$ & $|*| x \mid=2 x-5$ \\
\hline $5 x=50$ & Paniang $K L=2.10-5=20-5=15 \mathrm{~cm}$ \\
\hline$x=\frac{50}{5}=10 \longrightarrow 2 x-5=2(10)-5=20-5=15$ & ranjang $A L=2.10-20-3-13 \mathrm{~cm}$ \\
\hline$P$ jadi, panjang sisi $K M=20 \mathrm{~cm}$ & $* K L=L M=15 \mathrm{~cm}$ \\
\hline $\begin{aligned} \text { Sisi } M L=15 \mathrm{~cm} \\
\text { sici } K L=15 \mathrm{~cm}\end{aligned}$ & $x k M-x=10 \mathrm{~cm}$ \\
\hline$S_{1} S_{1} \quad K L=15 \mathrm{~cm}$ & \\
\hline
\end{tabular}

Figure 2. Student's Answer to Question Number 1

Item number 1 contains the ability to represent the pictorial aspect (image), symbol aspect, and also verbal. Students are asked to solve triangular problems in the form of picture questions to the verbal form. Students are asked to determine the type of triangle verbally (written) which is described in the problem according to its characteristics. Students can complete item number 1 point a by using their mathematical representation abilities in the pictorial and verbal aspects. While in item number 1 point $b$, students are asked to determine the lengths of the three sides of the KLM triangle. In the problem, there are several sides whose lengths are known in algebraic form (symbols), namely the KM side with a side length of $x$ and the side KL with a side length of $2 x-5$. With the help of both sides and the known perimeter of the triangle, students can determined the length of 
each side KLM triangle by determining the value of $x$ first. In this problem, students can use their representation abilities on the symbol aspect to operate algebraic forms so that the side length can be determined.

Based on Figure 1, SF students have been able to determine the type of triangle asked in the question. This is following the student's answer to number 1 point a, where the SF student wrote that the triangle formed was an isosceles triangle. Similar answers were also written by JRF students. Unlike SF students and JRF students, BSS students did not answer the question in point a. After the interview, it turned out that the BSS students forgot to write down the answers that should have been answered.

P : :Segitiga apa yang seharusnya terbentuk pada soal nomor 1 point a?"

BSS : "Segitiga sama kaki, karena ada 2 garis penandanya."

In question number 1 point $b$, students are asked to determine the lengths of the three sides of the KLM triangle. Of the three students, BSS students and JRF students were able to determine the length of each side of the triangle correctly. Before determining the length of each side of the triangle, the two students determine the value of $x$ first, and then with the known value of $x$, the two students can determine the length of each side of the KLM triangle. Unlike BSS and JRF students, SF students are less able to solve problem number 1 point $b$. This can be seen in the answers of SF students in Figure 1. After conducting interviews with these students, it turned out that the SF students were less thorough in solving problems.

SF : "Iya, seharusnya $40+10$, bukan $40-10 "$

In the problem of item number 2 , there are student answers as follows:

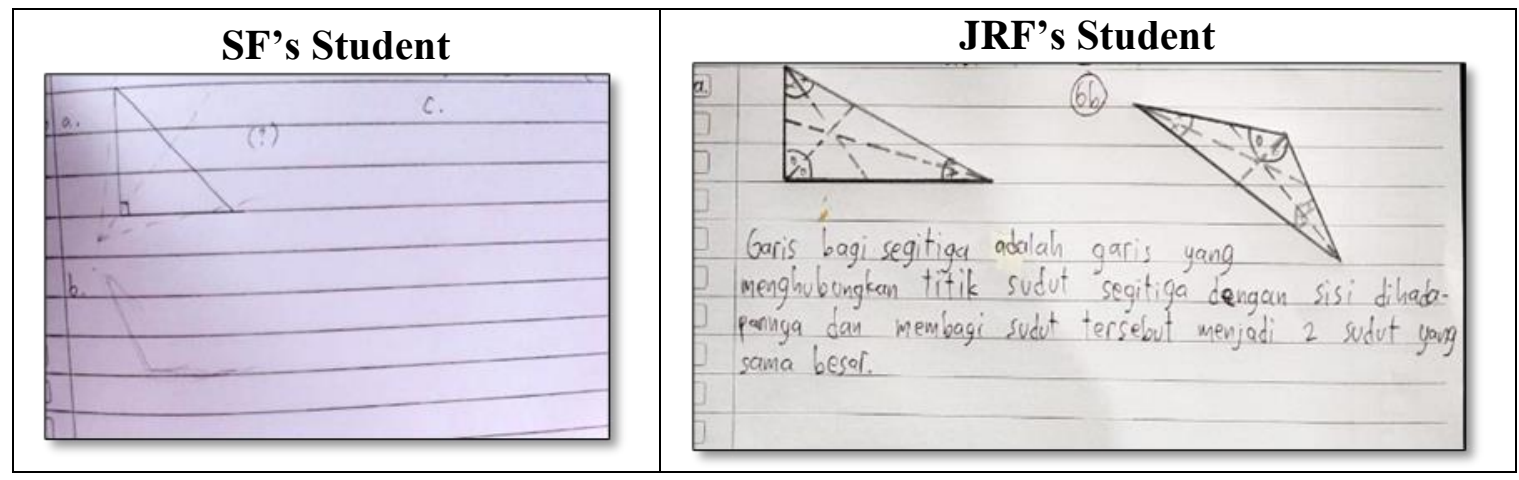




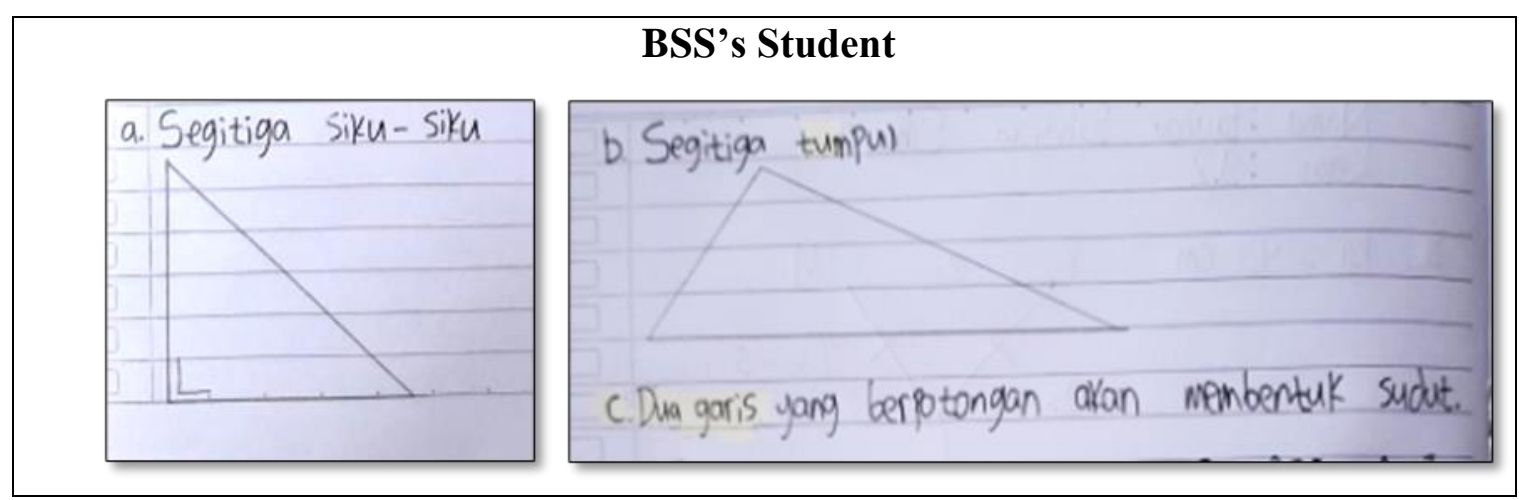

Figure 3. Student's Answer to Question Number 2

Item number 2 contains the ability of mathematical representation, where the aspects contained in item number 2 are the ability to represent verbal and pictorial aspects (pictures). Students are asked to solve problems from the verbal form into pictures. Students are asked to draw the bisector of a right triangle and an obtuse triangle. The bisector is one of the special lines found in a triangle that will divide two angles into the equal measure. In question number 2 points a and b, students can use their pictorial and verbal representation abilities. While in question number 2 point $\mathrm{c}$, students can use their verbal representation by generalizing a conclusion that is obtained based on their understanding of the dividing line into sentences.

Based on Figure 2 above, SF students are less able to solve the problems given. Seen in the answers of SF students who can only describe a right triangle with one bisector that has not been completed. Likewise in the answer to point $b$ which only describes the image of an obtuse triangle. In answer number 2 point c, SF students did not give any answers. This is because question point $\mathrm{c}$ is a student's answer that can be built after working on questions points $\mathrm{a}$ and $\mathrm{b}$. After the interview, the SF student stated that he did not understand what the bisector in a triangle meant.

In question number 2 points $\mathrm{a}$ and $\mathrm{b}$, BSS students also gave similar answers to SF students. While in the answer to point c, BSS students stated that the division gas was " $d u a$ garis yang berpotongan Akan membentuk sudut" which means two lines that intersect will form an angle.

Based on Figure 2, the answers given by the JRF to item number 2 points $a$ and $b$ correspond to what was asked. The answer given is correct. In the answer to point c, JRF students are also able to conclude what is meant by a dividing line according to their mathematical ideas after completing the answers to points $\mathrm{a}$ and $\mathrm{b}$.

Representations have different meanings so that they can be adapted to the context in question. From a psychological point of view, representation is a process of modeling a 
concrete thing in the real world into an abstract form or symbol. Whereas in mathematical psychology, representation means a description of the relationship between objects and symbols (Hwang et al., 2007). The discussion in this article is about representation in the scope of mathematics or mathematical representation.

Villegas et al., (2009) explained that “... the term representation refers to the forms with which we present to ourselves mathematical objects and processes, and which we find essential for defining, explaining, visualizing, recording and communicating mathematical knowledge". Hakim (2017) also argues that representation is an activity that involves translating an idea or problem into a new form.

On the other hand, Villegas et al., (2009) also explained that in the external representation there are three types of representation. Among them is 1) verbal representation of the word problem, 2) pictorial representation, 3) symbolic representation. These three types of representation are related to each other. Verbal representation of the word problem is a type of representational ability that consists of word or language problems. The word problem can be stated orally or in writing. Pictorial representation is a type of representational ability consisting of pictures, diagrams, or graphs and all things related to images. While symbolic representation is the ability to represent which consists of numbers, operations, algebraic symbols, and all things related to symbols.

\section{Verbal Representation}

Verbal representation ability is to represent which includes problems related to words or language. In the problem-solving process, several activities include verbal representation abilities. Based on the framework used by Villegas et al., (2009), seven problem-solving analysis guidelines are compiled to analyze representational abilities. It explains that activities that include verbal representation skills include internal representation of word and language problems, translation between verbal representations and images, translation between verbal representations and symbols, and events that are not classified into the other six representational analysis guidelines. In this discussion, the verbal representation ability in question is the translation between verbal and image, as well as events that are not classified into the other six guidelines for analyzing representational abilities. This is adjusted to the questions that have been given to students.

Based on the results of the research previously described, item number 1 is a question that contains mathematical representation skills in the verbal aspect, where students are asked to solve problems in the form of pictures (pictorial) into verbal form. 
That is, in solving the triangle problem that has been given students can use verbal representation skills. In the previous presentation, the three students were able to solve problem number 1 point a, where students were asked to represent the triangle picture on the question in verbal form by mentioning the type of triangle formed. The three students were able to distinguish triangles based on their types so that students were able to solve problems correctly. It can be seen in Figure 1, that SF and JRF students wrote answers with "isosceles triangles". Unlike the SF and JRF students, BSS students did not write down any answers to item number 1 point a. However, based on the results of the interview, the student was able to verbally explain the triangle shape formed by the image, namely an isosceles triangle. The student explained with a simple concept that the triangle described in the problem is isosceles because in the picture there are two marking lines that indicate the two sides have the same side length. So the triangle has two equal sides and a different side. This is following the characteristics of an isosceles triangle, where an isosceles triangle is formed by two sides that are the same length as the legs, and one side has a different length as the base of the triangle. This shows that students already understand the concept of the types of triangles.

As explained by Brenner quoted by Kartini that students' skills in representation can influence problem-solving correctly (Kholiqowati, 2016). This can be seen from the correct answers of the three students by mentioning that the triangle formed is isosceles. Therefore, it can be said that students with high ability, medium ability, and low ability can represent questions using verbal abilities by translating picture questions into verbal form.

While in item number 2, namely at point c, students are asked to provide conclusions which are expressions of verbal verification. Based on the analytical guidance framework (Villegas et al., 2009) the expression of verification is one of the seven representational events guidelines that cannot be classified into the other six representational ability analysis guidelines. Students are asked to verify the bisector that has been described in the answers to number 2 points $\mathrm{a}$ and $\mathrm{b}$ according to the students' understanding of the bisector of the triangle. The bisector of a triangle is a line drawn from the vertices of the triangle and divides the angle into two equal angles (As'ari et al, 2017). Of the three students, only JRF students who are students with high abilities can verbally generalize the bisector according to their understanding. Unlike the other two students, namely SF students and BSS students who are less able to solve problem number 2 point c. BSS students explained that "dua garis yang berpotongan akan membentuk sudut" which means two lines that intersect will form an angle. The BSS student's explanation is not wrong, because two 
intersecting lines will form an angle at the intersection of the lines. However, in the context of question number 2 point $\mathrm{c}$, the explanation is not appropriate, because it does not match the basic concept of the bisector of the triangle. SF students are also less able to solve problem number 2 point $\mathrm{c}$ which doesn't even explain anything related to what is meant by bisector of the triangle. This can be because BSS students and SF students do not understand what is meant by a bisector of the triangle, so they cannot solve the problem properly. This is in line with the results of research conducted by Kholiqowati, (2016) which states that not optimal student mastery of subject matter can cause students not to achieve the expected ability indicators. For this reason, it is necessary to have a maximum effort from all parties so that learning can be achieved following the goals that have been set (Chisara et al, 2018). One of them is by facilitating students with student learning resources so that learning objectives can be achieved (Arfianto \& Hakim, 2019). Based on the explanation above, it can be said that only students with high abilities can express verbal verification expressions appropriately.

\section{Pictorial Representation}

The ability to represent pictures (pictorial representation) is a representation that includes aspects of images, where students produce, operate, or modify image representations. Some indicators related to problem-solving using mathematical representation skills according to Villegas, et al., (2009) are students pointing or observing image representations and expressing terms related to pictorial representation and students drawing a representation using pencil and paper.

Item number 1 point a contains the ability to represent a picture, namely the disclosure of terms related to an image. In question number 1 point students are asked to explain the shape of the triangle described in the problem. As explained earlier in the explanation of verbal representation, that the three students were able to answer the questions correctly. This means that the student can distinguish the types of triangles based on their understanding by using verbal and pictorial representation abilities. So it can be concluded that students' ability to represent a picture, namely in expressing terms related to a picture, is good.

While item number 2 points a and $b$, students are asked to draw a bisector on a right triangle and an obtuse triangle. This shows that students can use their picture representation skills by describing a representation using pencil and paper.

Based on the previous presentation about the results of the research, SF students were less able to solve the problems given. Seen in the answers of SF students who can 
only describe a right triangle with one bisector that has not been completed. Likewise in the answer to point $b$ which only describes the image of an obtuse triangle. Similar to BSS students who only describe right triangles and obtuse triangles without the bisector of a triangle. Based on the presentation of students' picture representation abilities in question number 1 point an all students were able to express the term picture quite well. However, in the process of describing a representation in the form of pictures, students are less able to solve problems on the questions. Both students were only able to describe the shape of a triangle according to its type. This can be because the students have mastered the material on the types of triangles, but on the material for special segments of triangles, the two students have not mastered it optimally. So when asked to describe one of the special segments in the triangle, namely the bisector, the two students were not able to describe it. These problems can cause the mastery of the ability to represent the picture aspect to be less than optimal. This is following described by Kholiqowati, (2016) in his research which states that the student's mastery of the subject matter is not optimal yet can cause students not to achieve the expected ability indicators. Therefore, it is necessary to make efforts to increase students' mastery of the material, such as providing varied learning resources (Ayu \& Hakim, 2019), innovating learning models, methods, and learning methods used when teaching (Nurfadilah \& Hakim, 2019), and innovations in learning media such as math game applications (Hakim \& Sari, 2019), so that students can master the material to the maximum. This is expected to make it easier for students to solve problems properly using their pictorial representation abilities.

\section{Symbolic Representation}

Symbolic representation is the ability to represent numbers, operations, algebraic symbols, and all things related to symbols. Some of the activities included in symbol representation include students operating symbol representations by solving symbol expressions using stationery, students verbalizing how to solve equation problems, students modifying symbol expressions, and students observing or pointing at symbol expressions (Villegas et al., 2009). In learning mathematics, students learn knowledge related to formulas and numbers that can be used in solving number problems (Kurniasih \& Hakim, 2019). The symbol representation activity referred to in this study is that students can solve problems using symbol expressions in mathematical operations.

Item number 1 point $b$ contains the ability to represent symbols, where students are asked to determine the lengths of the three sides of the KLM triangle using mathematical operations. In this problem, it is known that the length of the side ML is $2 x-5$, and the 
length of KM is $x$. The side LM is equal to the side KL. It is characterized by an equal length marking line on both sides. Therefore, by using the formula for the perimeter of a triangle, students can calculate the length of each side of the KLM triangle by determining the value of $x$ first. In this problem, students should be able to complete algebraic operations with their mathematical representation abilities in the symbolic aspect. This is because students' ability to operate mathematics logically is one of the students' initial abilities in understanding mathematics (Erlina \& Hakim, 2019).

In the previous presentation about results studies, JRF students and BSS students were able to determine the length of each side in question by calculating the value of $x$ first with the equation of the perimeter of the triangle, where $x$ is $10 \mathrm{~cm}$. Using the known $x$ values, the two students were able to calculate the lengths of the three sides of the KLM triangle. Unlike JRF and BSS students, SF students who are students with low abilities have not been able to solve question number 1 point $b$ correctly. It can be seen in the results of the work of SF students, where SF students solve problems with incorrect answers. This can happen because students are less careful in calculating mathematical operations with incomplete steps. As seen in the 3rd-row operation, which is $5 x=\frac{30}{5}$. SF students should write $5 x=\frac{50}{5}$. SF students also admit that the answers given are not quite right, and know where the answers are wrong so that the calculated $x$ value is not quite right. As mentioned by Hijriani et al., (2018) that in solving problems, junior high school students are less careful so that students have not been able to represent symbolically and visually correctly.

Not only in the value of $x$, but SF students also did not continue to take steps to solve the problem. Where SF students answer up to the value of $x$ has been obtained. In fact, in item number 1 point $b$, students are asked to calculate the length of each side with the help of the $x$ variable. This can be caused by SF students being confused about substituting the variable $x$ on the known length of each side. This is like the results of research conducted by Dewi \& Sopiany, (2017) that the average student is confused in determining how to calculate operations that have variables. So that SF students are not able to solve the problem in question number 1 point $b$. Therefore, efforts are needed to help students by providing material in a way that is easily understood by students (Turrosifah \& Hakim, 2019), so that students are not confused when given questions due to misunderstanding in solving problems (Suciati \& Hakim, 2019). 
Based on the results of the explanation above, it can be said that the symbolic representation ability of students who have high and moderate abilities is quite good. It can be seen that both students can translate the picture into mathematical operations and can complete these mathematical operations. Meanwhile, students with low abilities lack the ability of symbolic representation. This is because, even though students with low abilities can translate the picture into the form of mathematical operations, these students are less careful in calculating mathematical operations. In addition, these students also lack the skills to operate algebraic forms, so the problems they face cannot be solved. Therefore, it is necessary to make efforts to improve students' skills in operating algebraic forms. One of them is by training students' skills by often providing practice questions in the form of algebraic operations.

\section{CONCLUSION}

Based on the results of data analysis and descriptive discussion above, it can be concluded that students' representational abilities in solving problems are different. In the aspect of verbal representation, the students' mathematical representation ability in translating pictures into verbal form is already owned by the three students with different levels of ability, namely high ability, medium ability, and low ability. Meanwhile, the students' representation ability in expressing verbal verification expressions is still lacking. Only students with high abilities can solve problems related to verification expressions.

In pictorial representation, students with all levels of ability can express terms related to a picture, while describing a picture using their representational abilities they are still lacking. Only students with high abilities can solve the questions asked. In the aspect of symbolic representation ability, the three students were able to operate algebraic forms, although one of the students was less careful in the completion process which resulted in the calculated results being incorrect.

Based on the explanation of the conclusions above, it is still necessary to make efforts to improve students' mathematical representation abilities. This is caused by several factors, including the lack of student mastery of the learning material. For this reason, innovation is needed both in learning and the media or teaching materials used in learning mathematics, so that students are expected to be able to solve problems using their representational abilities. 


\section{REFERENCES}

Adilah, N. (2015). Analisis Soal-Soal Dalam Buku Siswa Matematika Kurikulum 2013 Kelas VIII Semester I Terbitan Kemendikbud Berdasarkan Dimensi Kognitif Dari Trends In International Mathematics And Science Study (TIMSS). Jurnal Review Pembelajaran Matematika, 1(1), 86-98.

Andriani, P. (2015). Penalaran Aljabar dalam Pembelajaran Matematika. Beta, 8(1), 1-13.

Arfianto, H., \& Hakim, D. L. (2019). Penalaran matematis siswa pada materi fungsi komposisi. Prosiding Seminar Nasional Matematika Dan Pendidikan Matematik, 2018, 1248-1256.

As'ari, A. R., Tohir, M., Valentino, E., Imron, Z., \& Taufiq, I. (2017). Buku Siswa Matematika Kelas VIII Semester 2. In NASPA Journal (Edisi Revi, Vol. 42, Issue 4). Pusat Kurikulum dan Perbukuan, Balitbang, Kemendikbud.

Ayu, P. T. P., \& Hakim, D. L. (2019). Motivasi Belajar Siswa dalam Proses Pembelajaran. Prosiding Seminar Nasional Matematika Dan Pendidikan Matematika (Sesiomadika), 1146-1154.

Chisara, C., Hakim, D. L., \& Kartika, H. (2018). Implementasi Pendekatan Realistic Mathematics Education (RME) dalam Pembelajaran Matematika. Prosiding Seminar Nasional Matematika Dan Pendidikan Matematika (Sesiomadika), 65-72.

Creswell. (2009). Research Design (Qualitative, Quantitative, and MixedMethods Approaches (Third Edit). Thousand Oaks, California: SAGE Publications, Inc.

Dewi, S. V. P., \& Sopiany, H. N. (2017). Analisis Kemampuan Representasi Matematis Siswa Smp Kelas Vii Pada Penerapan Open-Ended. Prosiding Seminar Nasional Matematika Dan Pendidikan Matematika (SESIOMADIKA), 1, 680-688.

Erlina, \& Hakim, D. L. (2019). Kecerdasan Logis Matematis Siswa SMP pada Scaffolding. Prosiding Seminar Nasional Matematika Dan Pendidikan Matematika (Sesiomadika), 2014, 1165-1173.

Fauzan, A. (2013). Keefektifan Pembelajaran MEAs dengan Mengintegrasikan NKB terhadap Kemampuan Representasi Matematis dan Self-Efficacy pada Siswa Kelas X. In Skripsi. Semarang: Universitas Negeri Semarang tidak dipublikasikan.

Gumilang, G. S. (2016). Metode Penelitian Kualitatif dalam Bidang Bimbingan dan Konseling. Jurnal Fokus Konseling, 2(2). http://ejournal.stkipmpringsewulpg.ac.id/index.php/fokus/a

Hakim, D. L. (2017). Penerapan Mobile Learning Dalam Mengembangkan Kemampuan Komunikasi Matematis, Representasi Matematis, Dan Kemandirian Belajar Matematika Siswa. Thesis. Universitas Pendidikan Indonesia.

Hakim, D. L., Herman, T., \& Kartasasmita, B. G. (2020). The use of mobile learning at SMP Negeri 3 Karawang Barat in improving students' mathematical representation ability. Journal of Physics: Conference Series, 1663(1).

Hakim, D. L., \& Sari, R. M. M. (2019). Aplikasi Game Matematika Dalam Meningkatkan Kemampuan Menghitung Matematis. Jurnal Penelitian Dan Pembelajaran Matematika, 12(1), 129-141.

Hijriani, L., Rahardjo, S., \& Rahardi, R. (2018). Deskripsi Representasi Matematis Siswa SMP dalam Menyelesaikan Soal PISA. Jurnal Pendidikan: Teori, Penelitian, Dan Pengembangan, 3(5), 603-607.

Huda, U., Musdi, E., \& Nari, N. (2019). Analisis Kemampuan Representasi Matematis Siswa Dalam Menyelesaikan Soal Pemecahan Masalah Matematika. Ta'dib, 22(1), 19

Hwang, W. Y., Chen, N. S., Dung, J. J., \& Yang, Y. L. (2007). Multiple representation skills and creative effects on mathematical problem solving using a multimedia whiteboard system. Educational Technology and Society, 10(2), 191-212.

Kholiqowati, H. (2016). Analisis Kemampuan Representasi Matematis Ditinjau dari 
Karakteristik Cara Berpikir Peserta Didik dalam Pembelajaran dengan pendekatan Saintifik. Skripsi.

Kurniasih, R., \& Hakim, D. L. (2019). Berpikir Kritis Siswa dalam Materi Segiempat. Prosiding Seminar Nasional Matematika Dan Pendidikan Matematika (Sesiomadika), 1135-1145.

National Council of Teachers of Mathematics. (2000). Principles and Standards for School Mathematics. United States of America: The National Council of Teachers of Mathematics, Inc.

Novianti, M., \& Retnawati, H. (2019). Student-teacher's perception of mathematical representation in mathematics learning. Journal of Physics: Conference Series, $1320(1)$.

Nurfadilah, S., \& Hakim, D. L. (2019). Kemandirian Belajar Siswa dalam Proses Pembelajaran Matematika. Prosiding Seminar Nasional Matematika Dan Pendidikan Matematika (Sesomadika), 1214-1223.

Nurjanah, U., \& Hakim, D. L. (2019). Number sense siswa pada materi bilangan. Prosiding Seminar Nasional Matematika Dan Pendidikan Matematika Sesiomadika 2019, 2(1e), 1174-1182.

Putri, R. S. P., \& Munandar, D. R. (2020). Kemampuan Representasi Matematis Siswa Dalam Pemecahan Soal Matematika Pada Materi Bilangan Bulat Dan Pecahan. Prosiding Sesiomadika, 2(1a), 267-284.

Sari, M., Yusmin, E., \& T, A. Y. (2021). Kemampuan representasi matematis siswa pada materi segitiga 1 1,2,3. Jurnal Alpha Euclid Edu, 2(1), 122-128.

Suciati, D. R., \& Hakim, D. L. (2019). Koneksi Matematis Siswa Pada Materi Kubus dan Balok. Prosiding Seminar Nasional Matematika Dan Pendidikan Matematika (Sesiomadika), 1155-1165.

Triono, A. (2017). Analisis Kemampuan Representasi Matematis Siswa Kelas Viii Smp Negeri 3 Tangerang Selatan. Skripsi, Universitas Negeri Islam Syarif Hidayatullah Jakarta.

Turrosifah, H., \& Hakim, D. L. (2019). Komunikasi Matematis Siswa dalam Materi Matematika Sekolahan. Prosiding Seminar Nasional Matematika Dan Pendidikan Matematika (Sesiomadika), 2000, 1183-1192.

Villegas, J. L., Castro, E., \& Gutiérrez, J. (2009). Representations in problem-solving: A case study with optimization problems. Electronic Journal of Research in Educational Psychology, 7(17), 279-308. 